\title{
Steel Scrap Markets in Europe and the USA
}

\author{
by PATRIK SÖDERHOLM and THOMAS EJDEMO \\ Economics Unit, Luleå University of Technology, Luleå, Sweden
}

\begin{abstract}
The objective of this paper is to provide an overview of the market for steel scrap (or ferrous scrap) for steelmaking. A simple theoretical discussion of scrap markets is outlined, and it constitutes the basis for a discussion of consumption and supply behaviour, international trade patterns and the development of scrap prices over

time and across world regions. The geographical scope is essentially worldwide, but particular attention is paid to market behaviour and outcomes in Europe and the USA. In pursuing the above, the paper also reviews past research efforts on steel scrap markets and identifies topics for future economic research in the field. It is
\end{abstract}

\section{INTRODUCTION}

Recycling is assuming increasing importance in modern, rich societies today, both in a physical sense and in the perceptions about desirable change of economic activity and behaviour. Historically, recycling has occurred because it has been economical from a private viewpoint and recycling rates have often been substantial even in the absence of policy intervention. For instance, lead scrap has constituted about fifty per cent of the raw materials used in lead production and scrap-based production accounts for around forty per cent of global steel production (Jernkontoret 2003). The above implies that for many scrap materials, a global industry has developed on the basis of profit incentives, and scrap prices are determined by demand and supply in these markets. Scrap markets are typically highly competitive and there is thus little scope for producer pricing arrangements (e.g. Tilton 1992). An indepth understanding of the functioning of scrap markets is important not only for industry actors but it also constitutes a valuable input into the government decision-making process on the design and evaluation of different policy instruments. Two issues can illustrate this.

First, far-reaching policy measures are undertaken in many countries to promote the recycling of different scrap materials. The array of public policies includes, for example, surcharges on the disposal of recyclable materials, tax incentives and subsidies to recycling programmes, mandated minimum recycled material content to products, virgin material taxes etc. However, the rationale for and the understanding of the consequences of these measures are often less than complete, and attempts to promote recycling levels beyond the market-clearing level need to address the consequences and the importance of market behaviour. For instance, if the economic supply of scrap materials is very price inelastic, fiscal subsidies directed towards the recovery of these materials will only have limited impact. The relative costeffectiveness of different policies aimed at increasing recycling levels will also depend on market behaviour (Palmer et al. 1997). Moreover, while policy instruments are often national, the relevant markets are often international in scope and the resulting cross-border interdependencies must be taken into account as well (e.g. Huhtala and Samakovlis, 2002).

Secondly, the economic analysis of scrap markets also concerns an important methodological allocation problem in environmental lifecycle assessment (LCA) (Ekvall 2000). Specifically, for a product life cycle that involves the inflow and/or outflow of recycled materials, the question 
arises as to what extent the environmental burdens of primary material production and final waste disposal should be allocated to the product investigated (as opposed to other products where the material is used). In the case of economically traded materials these indirect effects can be assessed properly by modelling the relevant market behaviour and, as such, the analysis helps to make LCA a more effective tool for assessing the environmental impacts of different products and services (Ekvall 2000).

This paper aims at providing an overview of the market for steel scrap (or ferrous scrap) for steelmaking. It discusses consumption and supply behaviour, international trade patterns and the development of scrap prices over time and across world regions. The geographical scope is essentially world-wide, but particular attention is paid to market behaviour and outcomes in Europe and the USA. In pursuing the above, the paper also reviews past research efforts on steel scrap markets, and identifies topics for future economic research in the field.

The paper proceeds as follows: the next section briefly discusses the role of scrap material as an input in steel production and the main features of the recycling industry. A simple theoretical framework for analysing the functioning of scrap markets is outlined. Two subsequent sections provide an overview of scrap consumption and price developments world-wide, with particular emphasis on the situation in Europe and the USA. The paper ends with a brief section on the (partly separate) market for stainless steel scrap and by outlining some concluding remarks and implications.

\section{STEEL PRODUCTION AND THE ROLE OF SCRAP} RECYCLING

The Supply and Consumption of Scrap in Steel Production

Steel materials have had profound impact on the development of society. Its strength and durability makes it an ideal material for use in the construction and automotive industries, but it is also a material commonly used for various kinds of packaging and an array of other products. There are two dominating processes in modern steel production.

- Production from virgin iron ore, where iron oxide is reduced to hot metal (pig iron) in a blast furnace, and then refined to steel in a Basic
Oxygen Furnace (BOF). This refining process produces excess heat that allows steel scrap to be added to the melt. About sixty per cent of world steel production is iron ore-based (Jernkontoret 2003).

- Production from steel scrap, where scrap is molten in an Electric Arc Furnace (EAF), sometimes followed by refining. Highly alloyed steel grades such as stainless steel and tool steels are generally produced from scrap. ${ }^{1}$ The type of scrap used, as well as additions such as chromium and nickel, determines the properties of the produced material. Scrap-based production accounts for less than forty per cent of global crude steel production (Jernkontoret 2003).

Figure 1 provides an overview of how scrap is used in both of the above processes. End-of-life products and other sources of scrap are collected and processed by the scrap industry and can then be made readily available for re-melting. As noted above, excess heat in the BOF allows for some scrap to be added to the melt, but the primary raw

Figure I. Scrap Flows in Steel Production. BOF, Basic Oxygen Furnace; EAF, Electric Arc Furnace.

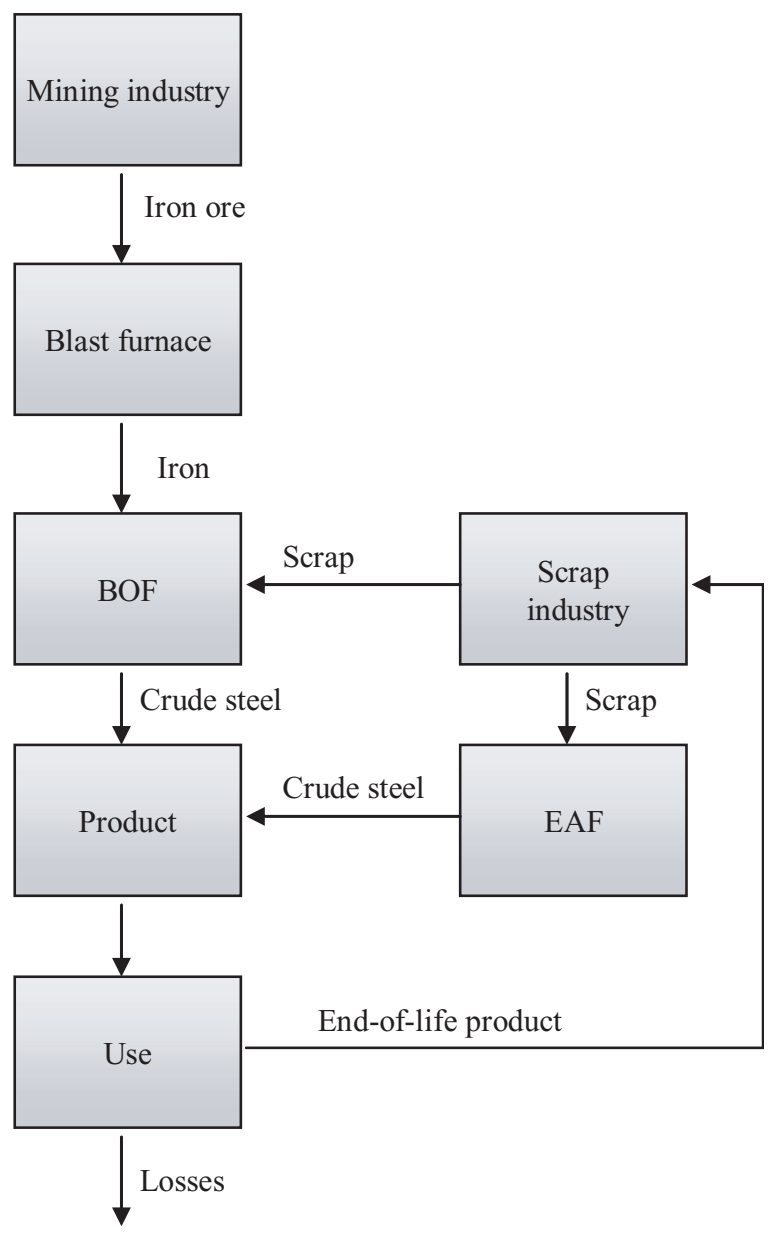


material is still iron ore. Steel production in the EAF is, in contrast, heavily dependent on scrap supplied by the scrap-processing industry as the basic raw material. While Figure 1 provides a rather schematic picture of the flows of steel scrap it is necessary to present a more detailed discussion of where scrap arises, and is finally made available for re-melting, as well as of the steel industry's incentive to use different types of scrap materials.

There are three basic sources of steel scrap. First, home scrap consists of scrap arising internally at steel mills in the form of rejects from melting, casting rolling, etc. Due to improved efficiency in production, the quantities of home scrap have decreased over time (Fenton 2004). This type of scrap requires no recovery process (i.e. it never becomes waste) and, as its composition is known, it is readily available for re-melting. The recovery of home scrap is managed within the steel mill and is therefore not handled by the recycling industry. The amount of home scrap generated differs across various mills, but it typically represents around ten per cent of total production (Jernkontoret 2003).

Secondly, new scrap comprises scrap that is generated when steel is fabricated into finished products. This scrap is generally of high quality with well-known compositions, and can therefore be quickly sold back to the steel plant either through scrap dealers or straight from the manufacturer (Fenton 2004). Estimating the volumes of new scrap generated within the manufacturing industries is a cumbersome task. Some sources indicate, however, that these volumes generally represent around thirteen to sixteen per cent of the total amount of steel that flows through the manufacturing industry, with a slightly higher volume of twenty per cent for the automotive industry (Jernkontoret 2003). Just as with home scrap, new scrap requires little processing and can be transported quickly back to the steel mill either through scrap processors or directly to the steel plant to avoid storage costs (Fenton 2004).

Thirdly, and finally, old scrap stems from obsolete steel products that have come to the end of their useful lives. These are collected, processed to certain specifications and finally sold back to steel plants for re-melting. Typical sources of old scrap are, for instance, automobiles, railroad cars and tracks, and steel structures. The recycling industry is essential for the supply of steel scrap (in particular old scrap). It comprises scrap brokers, collectors and processors. Scrap that requires processing before it can be made available for re-melting is collected by scrap processors or through the municipal waste disposal system. The scrap is then processed into a physical form and chemical composition that steel producers can consume. Scrap brokers organize transactions between buyers and sellers and receive a fee for this service (Fenton 2004).

A particularly important source of old scrap is discarded automobiles, which require significant processing before the scrap can be re-melted into new steel. Automobiles are processed in so-called shredders that fragment the vehicle into highdensity fist-size pieces, ideal for direct feeding into a steel furnace. Shredder plants are also capable of processing other consumer durables that would otherwise pose grave disposal problems (Bureau of International Recycling 2007). Other examples of processing include cutting large pieces of steel into more manageable sizes, sorting (by hand or automated) and pressing scrap into bundles to reduce volume and shipping costs. Estimating the availability of old scrap is difficult as many steel products have circulation times of a couple of decades before they become obsolete and finally are available for recycling (Jernkontoret 2003). The overall steel recycling ratio is therefore also difficult to estimate but previous studies suggest that is in the range of sixty to seventy per cent (Jernkontoret 2003).

\section{The Economic and Environmental Benefits of Steel Scrap Use}

There exist strong economic incentives to use scrap materials for steel production. Steel essentially does not suffer any downgrading when scrap is recycled, and it can thus almost be recycled indefinitely (EUROFER 2006). Scrap-based steel production using EAF is attractive as it has significant economic and environmental advantages over iron ore-based production. Jernkontoret (2003) stated that the energy requirements for producing 1 tonne of steel from virgin iron ore amounts to $23 \mathrm{GJ}$, while the same amount of steel can be produced from scrap using only $7 \mathrm{GJ}$ of energy. Scrap-based production using EAF is thus considerably cheaper in terms of energy costs. Furthermore, the process chain from scrap to steel involves fewer steps and less costs compared to iron ore-based production. These cost savings 
provide the main economic incentive for recycling of steel scrap and constitute the main reason why the steel industry has used scrap over the last one hundred and fifty years (Jernkontoret 2003; EUROFER 2006).

Recycling of steel represents not only a means of acquiring raw materials; the activities also save virgin natural resources, reduce pollution and prevent accumulation of ferrous waste that would otherwise be disposed of in landfill sites and the like. Emery et al. (2002) provided some noteworthy numbers on the merits of steel recycling: every tonne of recycled steel saves approximately 1.1 tonne of iron in ore, 0.6 tonnes of coal and $54 \mathrm{~kg}$ of limestone. Recycling also results in eighty-six per cent less air pollution, seventy-six per cent less water pollution, forty per cent reduction in water use, and reduces generation of solid waste by about 1.3 tonnes. Given these environmental benefits, it is easy to understand that there exists a public interest in maintaining a well-functioning recycling industry and in promoting recycling further with the help of tailormade policy instruments. Nevertheless, the extent and the design of any policy intervention requires thorough analysis and, on a general level, pollution externalities provide a stronger rationale for public policy intervention in the recycling industry than do resource scarcity concerns (e.g. Söderholm 2006).

Finally, although scrap is a vital raw material for steel production, there is some degree of substitution between steel scrap and Direct Reduced Iron (DRI). DRI is produced by reducing oxygen from iron ore through the use of carbon oxide and hydrogen gas produced from natural gas. It is used as a complement in EAFs and acts as a 'dilutent sweetener' to compensate for contaminants in the steel scrap. According to Chemlink (2007), DRI competes only with higher grades of scrap, and enables producers to use lower grades of scrap if the premium for high-quality scrap is high. In 2005 about 1.7 million tonnes of DRI were used in the USA as a substitute for steel scrap, amounting to only about 2 per cent of total scrap consumption (Fenton 2006).

The Structure of the European and US Steel Industries Later in this paper attention is paid to the production and use of steel scrap in Europe and the USA. Both these regions are large producers of steel and consume considerable amounts of scrap, but the structure of their respective steel industries is not homogeneous. The US steel industry is quite scrap intensive, with fifty-five per cent of its 2005 output coming from scrap-based production. The corresponding share for Europe is about forty per cent. It is useful to discuss briefly how these differences can be attributed to the respective industry structures.

In the past, steel production in the USA was dominated by large integrated plants, which produced steel from virgin iron ore. Technical changes after the Second World War allowed blast furnaces to increase their minimum efficient scale to more than 3 million tonnes per year (Crandall 1996). However, as US demand growth slowed down in the 1960s, scrap prices fell relative to iron ore costs. The large integrated mills were tied up in expensive labour agreements and faced increasing costs, which caused steel fabricators to search for cheaper sources of steel. This sparked the entry of new producers, using small-scale electric furnaces which quickly became known as minimills (Barnett and Crandall 1986). The history of steelmaking in electric furnaces is long, but the new minimills exploited technological improvements in melting and casting to reach previously unseen levels of success for electric steelmaking. Minimills involve much lower sunk costs compared to the huge integrated plants, and the production process is less energy and labour intensive. During the 1990s, capital costs for integrated steelmaking amounted to at least \$US700 per tonne, while the corresponding cost for minimills was typically not higher than \$US150 per tonne (Barnett and Crandall 1986). ${ }^{2}$

By 1996, the minimills had increased their share of US steel production to more than thirty-five percent. This share has continued to grow at the expense of integrated steel plants and, in 2005, about fifty-five percent of US crude steel output came from electric steel production (International Iron and Steel Institute (IISI) 2006). Minimills have, of course, spread across the world, but the growth in the USA has been particularly high, partly due to the country's reluctance to nationalize the domestic steel industry (Crandall 1996). The politics of the labour market, strong unions and perhaps a measure of pride have forced other governments to protect or cartelize large integrated steel plants.

In Europe the above restructuring of the steel industry has also taken place but it has not been 
equally strong. In 2005 about forty percent of European crude steel output came from electric furnaces (IISI 2006), but the integrated plants have often remained competitive. Sander (1996) suggested that US steel companies failed to modernize their plants in the 1950s and 1960s due to a lack of competition in the domestic market. During the same time period, however, European and Japanese producers made large investments in upgraded equipment. The superior technical status of Western Europe's integrated steel plants is therefore one of the most important explanations for the more modest growth of minimills in Europe. It is also worth noting that most North American minimills have started independently, while Western European electric furnaces have been developed within the structure of an integrated steel plant. Sander (1996) also noted that although the investment costs for a greenfield minimill are low, in Europe they can often be higher than the costs of modernizing existing integrated plants. Most European nations differ significantly from the USA in terms of wages and legislation, something that tends to make investment costs for European minimills considerably higher than for a US plant.

The Production and Recycling of Stainless Steel Although this report focuses on carbon steel, it is useful also to provide a basic overview of stainless steel production and recycling. The most important alloying materials in stainless steel are chromium, nickel and molybdenum, each adding properties such as corrosion resistance (Cr), ductility and toughness (Ni), and resistance to pitting and crevice (Mo). Chromium and molybdenum are similar in that they provide resistance to corrosion, but chromium is cheaper and thus more widely used. A typical stainless steel has a chromium content of seventeen to eighteen per cent (Jernkontoret 2003).

Virtually all stainless steel production is scrapbased. Recovered stainless steel scrap is melted in an EAF together with alloying materials. The carbon levels of the molten materials are then reduced in an Argon Oxygen Decarbonization (AOD) vessel, and final additions of alloying materials can be made (SSINA 2008). Producers may also use 'regular' carbon steel if there is a shortage of stainless scrap. This requires, though, far more additions of alloying materials (Jernkontoret 2003).
The sources of stainless steel scrap are similar to those of carbon steel scrap, and can be divided into home scrap, new scrap and old scrap. Just like carbon steel, old and new stainless steel scrap is collected, segregated by grade and cut to usable pieces by scrap processors. New scrap is valuable as its contents are known and the recycling process is thus relatively straight forward. Recycling of obsolete products (old scrap) is more labour intensive since the products require significantly more handling and the different materials need to be separated. Processors must analyse stainless scrap to determine its alloying contents in order to ensure not only quality, but also the value.

The industry organization Euro Inox (2008) concluded that any stainless steel object has an average recycled content of approximately sixty per cent, and stainless steel typically has an input composition of twenty-five per cent old scrap, thirty-five per cent new scrap and forty per cent virgin raw materials. Stainless steel is fully recyclable; however, due to the long lifetime of stainless steel products, together with a steadily increasing production, there is simply not enough scrap available. Euro Inox (2008) estimated that even if the average useful life was as short as twenty years, only thirty-five percent of today's production could be sustained by recovered scrap (assuming a one hundred per cent recovery rate).

\section{THE ECONOMIC FUNDAMENTALS OF SCRAP MARKETS}

This section uses Tilton's (1992) analysis and discusses some fundamental economics of scrap markets. The demand for and the supply of scrap metals are commented on in general, and the section ends by briefly discussing some implications for price behaviour in scrap markets.

Scrap metals seldom constitute final goods, but they possess certain qualities (strength, resistance to corrosion etc.) that make them useful in the manufacturing of final consumer goods. Due to this dependence on the demand for final goods, the demand for scrap metals is a 'derived' demand. Empirical studies typically indicate that the demand for scrap metals is relatively own-price inelastic (at least in the short run), i.e. the change in scrap consumption following a price increase for scrap material is fairly modest (e.g. Blomberg and Hellmer 2000). This is, in part, because: (a) few substitutes to the metal may exist; and (b) the processing of scrap metals can be rather capital intensive and substitution to other inputs is 
therefore costly and takes a considerable amount of time.

The above also implies that the demand for scrap metals is sensitive to changes in final demand, not least since metals are largely consumed in those sectors of the economy which tend to be particularly affected by fluctuations in the general business cycle. These include, for instance, capital equipment, consumer durables and the automobile industry. During a recession these sectors typically suffer far more than the economy as a whole, and the demand for scrap metals will fluctuate considerably over the business cycle. The next section of the paper pays particular attention to how steel scrap consumption is affected by current crude steel production levels. Clearly, in the steel case scrap-based production must remain competitive compared to iron ore-based production. For this reason the relative price of scrap versus virgin materials will also determine the demand for scrap metals.

When discussing the supply of scrap metals one needs to distinguish between the different types of sources of scrap supply, and the cases of new scrap and old scrap will be discussed separately. ${ }^{3}$ An important reason is that the availability of new and old scrap, respectively, is determined by different factors. It is assumed (realistically) that scrap markets are perfectly competitive, implying that scrap metal producers are price takers (see also below). In the case of new scrap, the amount available for recycling will be determined by the current level of metal consumption and the share of that consumption resulting in new scrap. Figure 2 shows the general shape of the shortand long-run supply curves for new scrap.

The long-run supply curve reflects the marginal cost of identifying, collecting and processing new scrap. A majority of the new scrap is relatively cheap to recycle and, for this reason, the supply curve is flat at low production volumes but as soon as it approaches the constraint given by current metal production levels it becomes considerably steeper (and ultimately vertical). Due to the low cost of recycling new scrap, almost all new scrap is recycled, implying that the constraint limiting supply in the short run will be essentially the same as the constraint in the long run. The short-run supply curve therefore becomes vertical at roughly the same output level, but, since in the short run producers need only cover their variable costs of production, it will lie below the long-run curve.

In the case of old scrap, it must be acknowledged that its availability during a given year depends both on the 'flow' of metal-containing products being scrapped during the year, as well as the 'stock' (i.e. accumulated past flows) of similar products, which have not been recycled in previous years (Tilton 1992). The fact that all scrap metal which is not recycled this year will add to the future stock of old scrap means that it is useful to make a distinction between supply emanating from the flow and the stock of old

Figure 2. Short- and Long-run Supply Curves for New Scrap. Source: Tilton (1992).

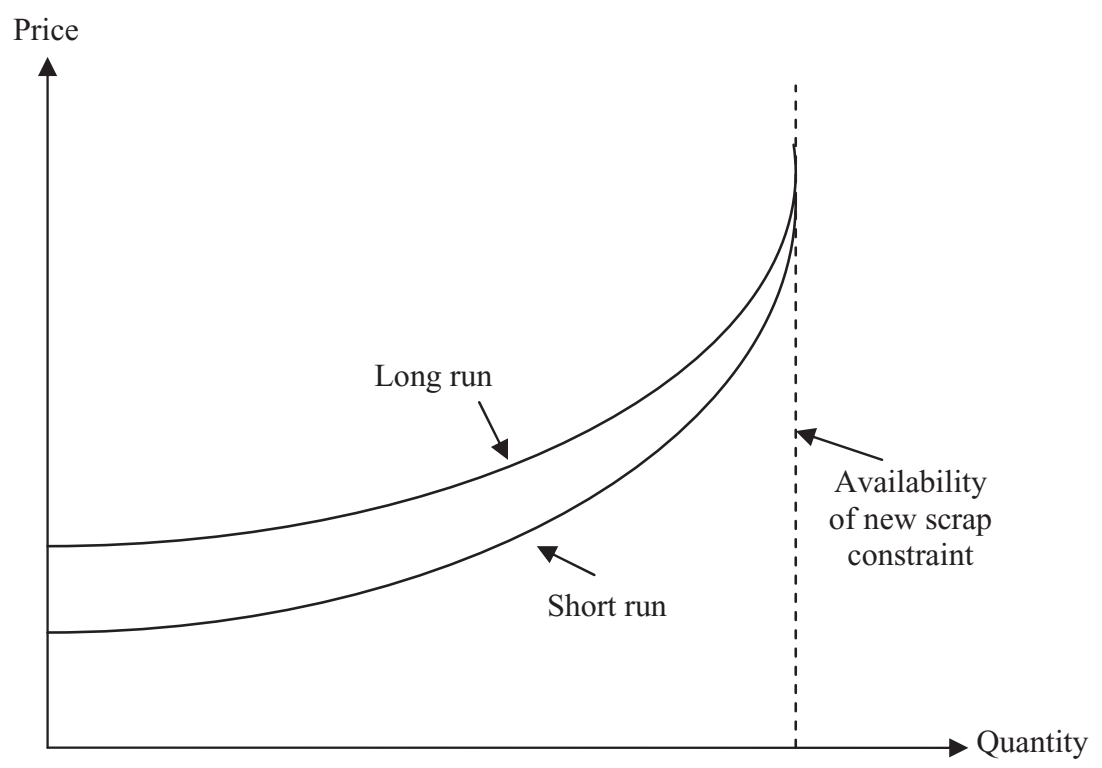


scrap, respectively. Figure 3 shows the short- and long-run supply curves for all types of old scrap. For simplicity, it is assumed that below the price level $P_{1}$ no metal from the stock of old scrap is recovered. In other words, the supply curve below this price level indicates solely the amount recovered from the flow.

The long-run supply curve for old scrap flow is likely to be steeper than the corresponding curve for new scrap, since old scrap is harder to identify and it is spread out geographically. It is assumed further that the short-run supply curve for production from the flow of old scrap lies below the long-run curve since in the short run producers will continue to operate as long as they cover their variable costs. ${ }^{4}$ The supply of scrap from the current flow is, of course, constrained by the total flow of old scrap during a particular year (but this constraint is not inserted in Figure 2).

If the price increases above $P_{1}$, one needs also to add the supply from the old scrap stock to the total picture and, at price $P_{2}$, the production from total old scrap equals $Q_{2}^{S}$ in the short run. However, this means that the stock of old scrap gradually depletes and what is recycled in one time period is not available for recycling in the next period. Thus, the constraint imposed by the availability of old scrap is more binding in the long run compared to the short run. Moreover, in the long run price $P_{2}$ will induce a lower level of production, $Q_{2}^{L}$, suggesting that the own-price elasticity of metal supply from old scrap is greater in the short run than in the long run. This result is also confirmed in empirical studies (e.g. Fisher et al. 1972). Still, the same studies also show that the own-price short-run supply elasticity for scrap metal often is fairly low (e.g. Blomberg and Hellmer 2000), not the least due to the rising marginal cost of processing old scrap and the availability constraints facing new scrap supply.

Given the competitive situation in most scrap markets, it is fair to assume that scrap prices will be determined by the intersection of the demand and the (total) supply curves. As several firms compete for market shares, prices are driven down towards the marginal cost of production. The combination of low own-price elasticities for demand and supply, on the one hand, and the high income elasticity of metal demand, on the other, implies that scrap prices often tend to fluctuate a lot over time in line with the business cycle and the resulting variations in metal demand. Over the long run, however, both demand and supply of metal scrap will be determined heavily by technological change, for instance, making scrap collection and processing cheaper over time and permitting increased use of the metal scrap. The rise of the steel minimill in the USA during the last decades is a good illustration of the latter effect (Barnett and Crandall 1986).

Figure 3. Short- and Long-run Supply Curves for Old Scrap. Source: Tilton (1992).

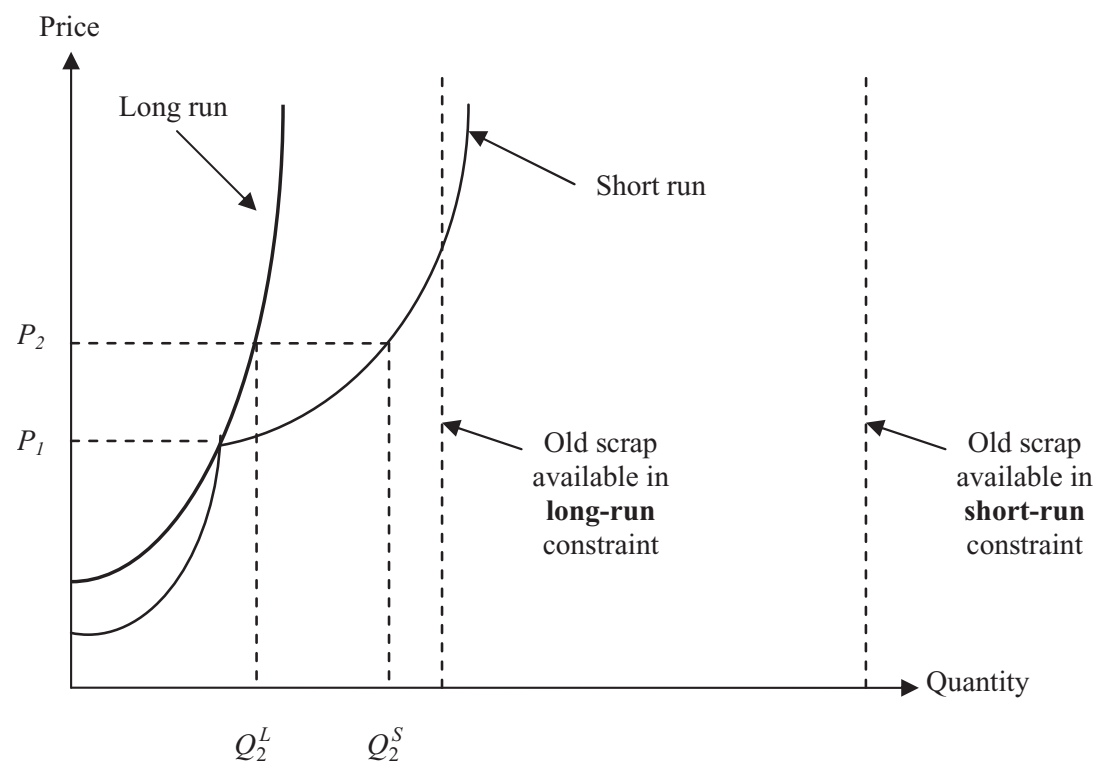


Because scrap has an economic value as a raw material, a well-functioning scrap market has developed over time even in the absence of public intervention (e.g. Fenton 2004; EUROFER 2006). The following three sections provide an overview of the market for steel scrap. The first section of the three illustrates the role of steel scrap consumption as derived demand for steel-based products, as well as the wide geographical scope of the steel scrap market. An entire section is then devoted to a discussion on price formation and price developments over time in these two regions, and how the interaction of supply and demand forces influences price formation is discussed. A separate section comments briefly on the world market for stainless steel scrap.

\section{STEEL SCRAP CONSUMPTION AND TRADE}

The demand for steel scrap is a derived demand; it stems from the demand for steel and ultimately from the products that are composed of steel. World steel production and the demand for steel have increased steadily during the last fifty years and, during the last decade, the rapid economic expansion of China (and other Asian countries) has further propelled the demand for steel. Table 1 summarizes the top-ten steel-producing countries for the years 2004 and 2005, showing that, in 2005, the share of Chinese steel production out of the world total amounted to thirty-one per cent. This represented a major relative increase compared to the year before, when the corresponding market share was twenty-six per cent.

Table I. Top-ten Steel-producing Countries, 2004 and 2005.

\begin{tabular}{lrrrrr}
\hline Country & \multicolumn{2}{c}{2005} & & & 2004 \\
\cline { 2 - 3 } \cline { 5 - 6 } \cline { 5 - 6 } & Rank & mmt & & Rank & mmt \\
\hline China & 1 & 349.4 & & 1 & 280.5 \\
Japan & 2 & 112.5 & & 2 & 112.7 \\
USA & 3 & 94.9 & & 3 & 99.7 \\
Russia & 4 & 66.1 & & 4 & 65.6 \\
South Korea & 5 & 47.8 & & 5 & 47.5 \\
Germany & 6 & 44.5 & & 6 & 46.4 \\
Ukraine & 7 & 38.6 & & 7 & 38.7 \\
India & 8 & 38.1 & & 9 & 32.6 \\
Brazil & 9 & 31.6 & & 8 & 32.9 \\
Italy & 10 & 29.3 & & 10 & 28.5 \\
Top-ten total & 852.8 & & 785.1 & \\
World total & $1,131.8$ & & $1,067.0$ & \\
\hline
\end{tabular}

Million metric tons $(\mathrm{mmt})$ crude steel production. Source: International Iron and Steel Institute (2006).
Table 2 shows that the top-ten companies produced roughly seventy-five per cent of total world steel production. EFR (2006) reported that in spite of the fact that the European steel industry contributes only a fraction of total world output, some of the largest steel companies in the world are from Europe. Specifically, the European Union twenty-five countries' share of world crude steel production is around sixteen to eighteen per cent, but four European companies rank among the top ten. These include Mittal Steel (Netherlands) in the top spot and Arcelor (Luxembourg) in second place (Table 2). The above also implies that the European steel industry owns production facilities in other countries. In Europe five steel producers represent approximately seventy per cent of the European market (EFR 2006).

We have noted above that approximately sixtyfive per cent of world crude steel is produced in integrated steel plants using the BOF, and less than forty per cent is produced using the EAF. Table 3 presents the corresponding figures by country for the year 2005, and it shows that while some countries appear to have a mix of the two technologies, others rely almost solely on either of the two. Again, the USA shows evidence of a stronger reliance on the EAF process compared to Europe as a whole (EU-25). A few countries in the former Soviet Union use other steelmaking technologies, such as the outdated open heart furnace (Yuzov and Sedykh 2003), but on a global scale this share is quite negligible. The data presented in Table 3 are of particular interest in this paper since electric steel production is highly dependent on scrap supply.

Table 2. Top-ten Steel-producing Companies, 2004.

\begin{tabular}{lll}
\hline Company & \multicolumn{1}{c}{ Country } & $\mathrm{mmt}$ \\
\hline Mittal Steel & Netherlands & 63.0 \\
Arcelor & Luxemburg & 46.7 \\
Nippon Steel & Japan & 32.0 \\
POSCO & South Korea & 30.5 \\
JFE & Japan & 29.9 \\
Baosteel & China & 22.7 \\
US Steel & USA & 19.3 \\
Nucor & USA & 18.4 \\
Corus Group & UK & 18.2 \\
Riva & Italy & 17.5 \\
\hline
\end{tabular}

Million metric tonnes ( $\mathrm{mmt}$ ) crude steel production. Source: International Iron and Steel Institute (2006). 
Table 3. Crude Steel Production by Process, 2005.

\begin{tabular}{|c|c|c|c|c|c|c|}
\hline \multirow[t]{2}{*}{ Country } & \multirow{2}{*}{$\frac{\text { Production }}{(\mathrm{mmt})}$} & \multirow{2}{*}{$\begin{array}{c}\text { Oxygen } \\
\%\end{array}$} & \multirow{2}{*}{$\begin{array}{c}\text { Electric } \\
\%\end{array}$} & \multirow{2}{*}{$\frac{\text { Open Heart }}{\%}$} & \multirow{2}{*}{$\begin{array}{c}\text { Other } \\
\%\end{array}$} & \multirow{2}{*}{$\frac{\text { Total }}{\%}$} \\
\hline & & & & & & \\
\hline Austria & 7.0 & 91.1 & 8.9 & - & - & 100.0 \\
\hline Belgium & 10.4 & 74.6 & 25.4 & - & - & 100.0 \\
\hline Czech Rep. & 6.2 & 91.0 & 9.0 & - & - & 100.0 \\
\hline Finland & 4.7 & 70.0 & 30.0 & - & - & 100.0 \\
\hline France & 19.5 & 62.5 & 37.5 & - & - & 100.0 \\
\hline Germany & 44.5 & 69.3 & 30.7 & - & - & 100.0 \\
\hline Hungary & 2.0 & 83.8 & 16.2 & - & - & 100.0 \\
\hline Italy & 29.3 & 39.9 & 60.1 & - & - & 100.0 \\
\hline Luxembourg & 2.2 & 0.0 & 100.0 & - & - & 100.0 \\
\hline Netherlands & 6.9 & 98.0 & 2.0 & - & - & 100.0 \\
\hline Poland & 8.4 & 59.1 & 40.9 & - & - & 100.0 \\
\hline Slovakia & 4.5 & 91.9 & 8.1 & - & - & 100.0 \\
\hline Spain & 17.8 & 24.5 & 75.5 & - & - & 100.0 \\
\hline Sweden & 5.7 & 68.9 & 31.1 & - & - & 100.0 \\
\hline UK & 13.2 & 79.6 & 20.4 & - & - & 100.0 \\
\hline Other EU & 4.2 & - & 100.0 & - & - & 100.0 \\
\hline EU-25 & 186.8 & 61.2 & 38.8 & - & - & 100.0 \\
\hline Romania & 6.2 & 72.3 & 27.7 & - & - & 100.0 \\
\hline Turkey & 21.0 & 29.2 & 70.8 & - & - & 100.0 \\
\hline Others & 5.5 & 43.7 & 56.3 & - & - & 100.0 \\
\hline Other Europe & 32.7 & 39.8 & 60.2 & - & - & 100.0 \\
\hline Russia & 66.1 & 61.6 & 16.3 & 22.1 & - & 100.0 \\
\hline Ukraine & 38.6 & 49.9 & 9.8 & 40.2 & - & 100.0 \\
\hline Other CIS & 8.6 & 51.5 & 40.1 & 8.4 & - & 100.0 \\
\hline CIS & 113.4 & 56.9 & 15.9 & 27.2 & - & 100.0 \\
\hline Canada & 15.3 & 58.5 & 41.5 & - & - & 100.0 \\
\hline Mexico & 16.2 & 27.8 & 72.2 & - & - & 100.0 \\
\hline USA & 94.9 & 45.0 & 55.0 & - & - & 100.0 \\
\hline NAFTA* & 126.4 & 44.4 & 55.6 & - & - & 100.0 \\
\hline Central \& South America & 46.3 & 61.5 & 37.3 & - & 1.2 & 100.0 \\
\hline Africa & 17.6 & 44.0 & 56.0 & - & - & 100.0 \\
\hline Middle East & 14.9 & 16.5 & 83.5 & - & - & 100.0 \\
\hline Asia & 582.8 & 76.4 & 23.5 & 0.2 & - & 100.0 \\
\hline World & 1129.6 & 65.4 & 31.7 & 2.8 & 0.1 & 100.0 \\
\hline
\end{tabular}

* North American Free Trade Agreement.

Source: International Iron and Steel Institute (2006).

Turning attention to the market situation in Europe, one notes that in 2005, the steel producers within EU-25 consumed about 101 million tonnes of steel scrap and, in that same year, 8.9 million tonnes of steel scrap were exported from the region, while the corresponding imports amounted to 7.4 million tonnes. EFR (2006) suggested that a combination of sixty-five percent old scrap and thirty-five per cent new scrap deliveries to EU-25 steel mills is a reasonable approximation. By breaking the total consumption figures for 2004 down to the country-level for the European steelproducing countries, it is found that Italy and
Germany are the most significant scrap consumers in Europe (Table 4). This should be no surprise since both these two countries are among the world's top-ten steel-producing countries.

Turkey is also a large consumer of scrap, and ITC (2007) data indicate that Turkey was the world's biggest importer of steel scrap during the time period of 2002-2005. Germany is the biggest exporter of steel scrap materials in Europe and, in fact, the world's second largest exporter after the USA. Other notable big exporters of steel scrap in Europe include France, the Netherlands and the UK. 
Table 5 provides more detailed information on the European international trade balance for 2004 and 2005, displaying the major (non-EU) buyers of European-supplied scrap as well as the countries of origin for the scrap imported into Europe. The data show that the international trade in steel scrap is substantial. Turkey is the most important buyer of European scrap, but scrap from Europe is also exported to rather distant countries, such as Malaysia, China, USA and South Korea. Moreover, a major share of the imported steel scrap entering Europe comes from Russia, but also from the USA and northern Africa (Morocco).

Turning attention to the US situation, it has already been noted that the steel producers within the NAFTA (North American Free Trade Agreement) region depend more heavily on scrap-based production compared to their European competitors (Table 3). The region is clearly dominated by the USA, which during 2005 produced about 95 million tonnes of crude steel (seventy-five per cent of total NAFTA crude steel output), and about fifty-five per cent of the US crude steel output comes from scrap-based EAF production. This scrap-intensive technology, coupled with the huge steel output, means that scrap consumption in the US steel industry is very large. IISI statistics for 2004 revealed that - with the exception of China - no other individual nation comes even close to the same scrap consumption of the USA (IISI 2006). Fenton (2006) showed that recycled scrap in the USA consists of approximately forty-nine per cent obsolete products (old scrap), twenty-six per cent new scrap and twenty-five per cent home scrap. Automobiles are the primary sources of old scrap, with an impressive recycling rate of one hundred and two per cent for the year 2004, i.e. the US steel industry recycled more steel from scrapped automobiles than was used in the domestic production of new vehicles during the same year. Table 6 provides scrap consumption, trade and apparent domestic supply for the NAFTA region. These numbers also reveal that the USA is a major net exporter of steel scrap, despite its very large consumption level.

Fenton (2006) reported that the most significant sources of scrap imports to the USA during the time period 2001-2004 were Canada (sixty per cent), UK (twenty per cent), Sweden ( 7 per cent), Russia ( 3 per cent) and other countries (ten per cent). In 2004, the scrap exports from the USA were destined mainly for China, Canada and Turkey, in descending order.

Table 4. Scrap Consumption, Trade and Apparent Domestic Supply in Europe, 2004 (mmt).

\begin{tabular}{|c|c|c|c|c|}
\hline Country & Consumption & -Imports & +Exports & $=$ Apparent domestic supply \\
\hline Austria & 2.3 & 1.0 & 1.1 & 2.4 \\
\hline Belgium-Luxembourg & 8.0 & 8.4 & 3.4 & 3.0 \\
\hline Finland & 2.2 & 0.9 & 0.3 & 1.7 \\
\hline France & 10.6 & 3.5 & 5.6 & 12.7 \\
\hline Germany & 20.6 & 5.4 & 7.0 & 22.2 \\
\hline Italy & 21.8 & 5.6 & 0.2 & 16.4 \\
\hline Netherlands & 1.7 & 2.6 & 4.1 & 3.1 \\
\hline Spain & 15.8 & 6.4 & 0.2 & 9.6 \\
\hline Sweden & 2.8 & 0.3 & 0.7 & 3.2 \\
\hline UK & 5.1 & 0.2 & 6.8 & 11.6 \\
\hline Other EU & 3.7 & 1.7 & 2.2 & 4.3 \\
\hline EU-15 Total & 94.5 & 36.0 & 31.6 & 90.1 \\
\hline Bulgaria & 1.1 & 0.1 & 0.8 & 1.8 \\
\hline Czech Republic & 2.9 & 0.5 & 1.6 & 4.0 \\
\hline Hungary & 0.8 & 0.1 & 0.9 & 1.6 \\
\hline Poland & 5.8 & 0.4 & 2.0 & 7.5 \\
\hline Romania & 2.8 & - & 2.4 & 5.2 \\
\hline Slovakia & 1.1 & 0.3 & 0.5 & 1.3 \\
\hline Turkey & 17.2 & 12.9 & 0.1 & 4.3 \\
\hline Others & 3.7 & 2.1 & 2.9 & 4.6 \\
\hline Other Europe Total & 35.4 & 16.3 & 11.1 & 30.2 \\
\hline
\end{tabular}

Source: International Iron and Steel Institute (2006). 
Table 5. EU-25 Steel Scrap Trade Balance, 2004 and 2005 (mmt).

\begin{tabular}{|c|c|c|c|c|c|}
\hline \multicolumn{3}{|c|}{ Exports third countries ex EU } & \multicolumn{3}{|c|}{ Imports third countries into EU } \\
\hline & 2005 & 2004 & & 2005 & 2004 \\
\hline \multirow[t]{2}{*}{ Total } & 8.887 & 9.547 & Total & 7.436 & 8.246 \\
\hline & Biggest buyers & & & Biggest suppliers & \\
\hline Turkey & 2.824 & 2.956 & Russia & 3.817 & 4.282 \\
\hline India & 2.073 & 0.640 & Switzerland & 0.567 & 0.590 \\
\hline USA & 0.771 & 2.005 & USA & 0.340 & 0.364 \\
\hline China & 0.408 & 0.398 & Norway & 0.289 & 0.297 \\
\hline Pakistan & 0.390 & 0.131 & Morocco & 0.156 & 0.154 \\
\hline Switzerland & 0.327 & 0.481 & Ukraine & 0.095 & 0.217 \\
\hline Malaysia & 0.298 & 0.834 & & & \\
\hline South Korea & 0.213 & 0.414 & & & \\
\hline Taiwan & 0.169 & 0.313 & & & \\
\hline Norway & 0.135 & 0.157 & & & \\
\hline Indonesia & 0.130 & 0.325 & & & \\
\hline
\end{tabular}

Source: EFR (2006).

Table 6. Scrap Consumption, Trade and Apparent Domestic Supply in the NAFTA Region, 2004 (mmt).

\begin{tabular}{lcccc}
\hline Country & Consumption & - Imports & +Exports & =Apparent domestic supply \\
\hline Canada & 8.6 & 1.8 & 3.0 & 9.7 \\
Mexico & 12.9 & 2.1 & 0.4 & 11.3 \\
USA & 59.7 & 4.6 & 11.9 & 67.0 \\
NAFTA* & 81.1 & 8.5 & 15.3 & 87.9 \\
\hline
\end{tabular}

* North American Free Trade Agreement.

Source: International Iron and Steel Institute (2006).

Again, these trade patterns show evidence of an essentially global market in steel scrap. This has important implications for the analysis of scrap market behaviour. Most notably, most countries will essentially be price takers and the world market price will thus be influenced by the derived demand for steel scrap in a large number of countries (and thus not only by domestic steel production levels). Scrap supply, on the other hand, is likely to be determined by the size and the structure (e.g. steel intensity) of the domestic economy.

\section{THE DEVELOPMENT OF STEEL SCRAP PRICES}

The global steel scrap industry displays no clear tendencies towards consolidation and it is perfectly competitive with relatively free entry and exit. The geographical scope of the market is essentially global. Figure 4 shows the development of scrap prices in Europe and the USA since
1999, and indicates that prices in the two world regions move fairly close to each other (although with some short-term deviations). The findings of Aylen and Albertson (2006) confirmed this conclusion. They used quarterly price data for the time period 1977-2005 and showed that US and European scrap prices are cointegrated, i.e. they follow the same long-term trend. ${ }^{5}$ Thus, although prices may diverge locally because of different seasonal patterns, market forces will pull them back together in the long run. By comparing these results to a similar study using earlier data series (1977-1992), the authors also concluded that the US and European scrap prices have become more closely cointegrated over time (with presently fewer short-run departures from the long-run trend) (Albertson and Aylen 1996).

This supports the conclusion that the economic market for steel scrap is essentially global in scope. Thus, any unilateral attempt on the part of a given nation aimed at influencing the market price will 
Figure 4. Price Development of US and European Steel Scrap (Index 100=200I).

Note that for Europe, the index has been calculated on the basis of average prices $(€)$ for France, Germany, Italy, Spain and the UK. Sources: EUROFER (2007) and Fenton (2002, 2007).

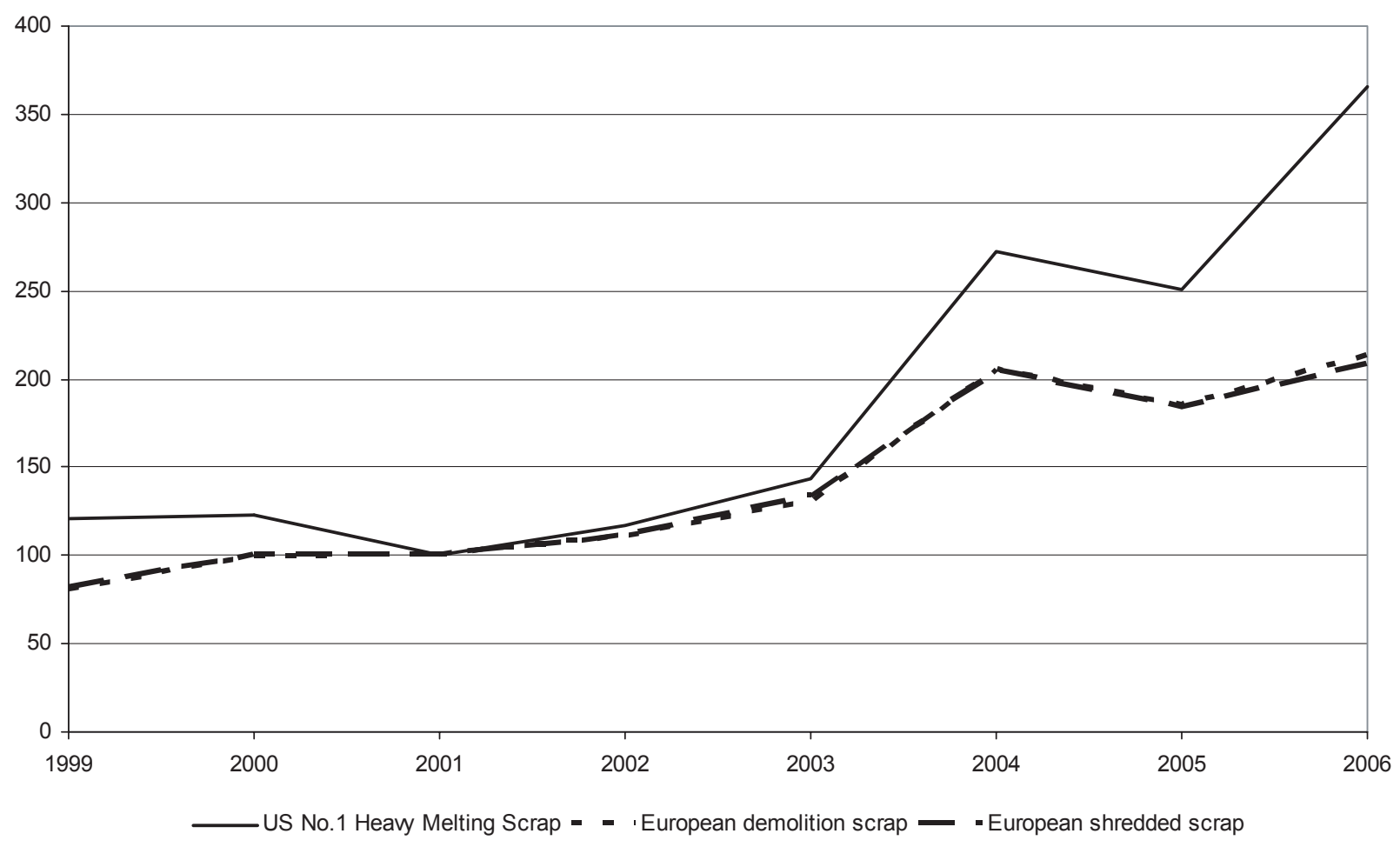

be futile. Figure 5 shows the development of scrap prices in the USA over the longer time period 1934-2006, and it confirms the picture of rather volatile prices over time. Scrap demand is derived from the demand for steel mill and foundry products, which, in turn, is affected heavily by the general business cycle. If steel demand is weak, scrap demand is low and prices will fall because of a fairly low own-price elasticity of supply in the short run. Barnett and Crandall (1986) estimated an econometric model of the US iron and steel scrap market, including a supply function for all purchased scrap (i.e. their data do not permit a separation of new and old scrap). ${ }^{6}$ The supply of purchased scrap is found to be related to scrap prices, and their results suggest an own-price elasticity of supply of 0.39 at the point of means. Barnett and Crandall (1986) also reported that export demand is only weakly sensitive to the value of the dollar, and not significantly affected by domestic scrap prices.

The high volatility of prices can, to some extent, be countered by the scrap industry through increasing inventory to absorb price differentials (Fenton 2004). Scrap prices tend to fall as inventories are run down at the end of a fiscal year, and then rebound as demand increases in the beginning of the next year and scrap stocks are rebuilt. Scrap prices also appear to have seasonal trends due to the effect of climatic conditions on transport costs, at least in the USA (Albertson and Aylen 1996; Evans 2006). Transport routes in the USA are affected heavily during winter when the Great Lakes of North America freeze, and years with severe winters may also affect rail transports. Albertson and Aylen (1996) observed spring and autumn peaks in scrap supply in the USA. ${ }^{7}$ Seasons are obviously different throughout the world and may therefore cause local prices to diverge temporarily from the long-run trend. Furthermore, Aylen and Albertson (2006) showed that episodic price bubbles and occasional price crashes are rare in the steel scrap market and thus represent mainly transient features of the market.

By looking at the history of scrap prices one can identify a number of instances of sharp responses to supply and demand forces. During the 1930s and the World War II period, demand increased and scrap prices increased up to the point where the US Government adopted price controls (Campbell 1948). Also, price controls were adopted during the Korean War (1950-1953). 
Figure 5. US Scrap Prices in Current and Real Terms, 1934-2006.

Sources: Fenton (2007) and US Geological Survey (2007).

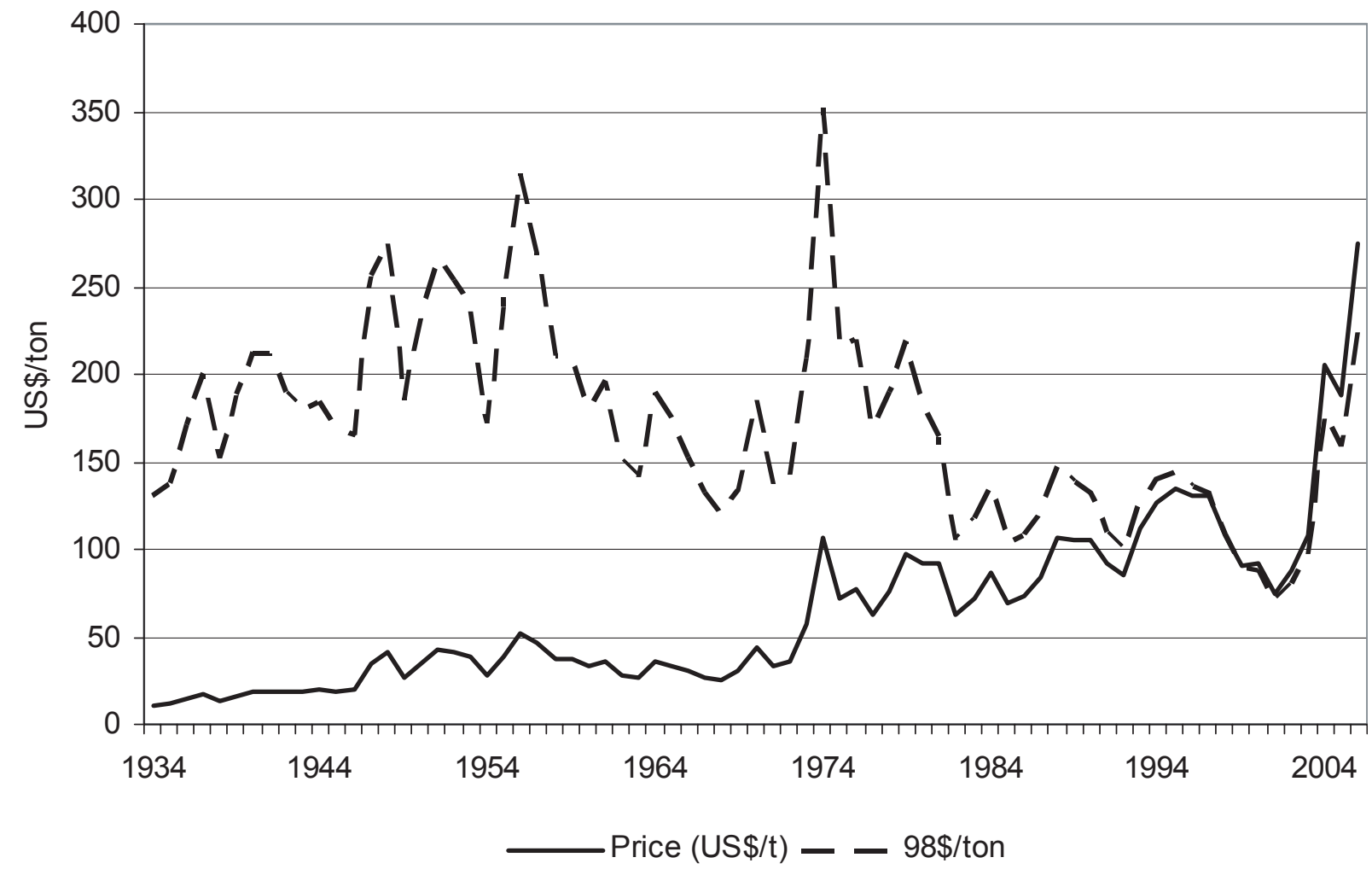

Figure 5 reveals an upward jump in 1974 which, according to Evans (2006), partly resulted from the oil price shock in 1973 and the subsequent inflation of commodity prices experienced by all Organization for Economic Co-operation and Development (OECD) economies. In addition to this, however, this period featured a dramatic decline in the demand for steel, forcing inefficient old technology out of production in favour of the EAF technology. The result was an increased demand for scrap steel, as the old technology had mainly used home scrap and virgin iron ore and EAFs depend heavily on scrap purchased in the market. Yuzov and Sedykh (2003) concluded that on a world-wide basis the supply of home scrap decreased by a factor of 1.6 also over the period 1980-2001, while the use of old and new scrap increased substantially. This increased demand in the mid-1970s caused scrap prices to rise and, as less steel was produced during the period, the supply of new scrap decreased, adding further to the price increases (Yuzov and Sedykh 2003).

The price development during the 1990s was shaped largely by steel demand changes. For instance, during the period 1993-1997 demand for steel increased world-wide and so did scrap prices. This was induced by the rapid economic growth in countries in Asia, Eastern Europe and Latin America (Fenton 2007). However, with the Asian financial crisis in 1997-1998 economic growth - and thus steel demand - halted, with a resulting decline in scrap prices as Asian steel production declined. In the beginning of the new millennium, however, scrap prices have increased significantly following the unprecedented increase in steel consumption in China and India. During the last 7-8 years China has completely dominated the growth segment of world steel production, and most past forecasts of Chinese steel production have become outdated very quickly. The industry analyst David Humphreys (2007: 1) reported:

As recently as 2000 , I recall debating with my then colleagues in Rio Tinto's iron ore business the level at which China's steel production would eventually plateau. Output at that time was running around at around 125 million tonnes but we knew something important was stirring. The consensus which 
emerged was that production might rise to 180 million tonnes before flattening out, although at stretch it might reach 200 million tonnes. The outlier of our group, on the basis of regional intensity of use analysis, argued that it might go to 300 million tonnes. In the event, in 2006 only six years later, it actually sailed through 400 million tonnes, way more steel than any country has ever produced before.

Aylen and Albertson (2006) investigated the price data to test if the recent increase in scrap prices is a temporary bubble, i.e. a self-fulfilling prophecy among market actors that prices will rise above a sustainable level in the short run, or a break in the trend. Their results reject the bubble hypothesis and suggest that the price increase represents normal market behaviour.

The above discussion has focused on the shortrun price movements of steel scrap, and it has been illustrated how the simple theoretical framework outlined above can be used to understand price movements over time. Empirical research also confirms the finding of a relatively low own-price elasticity of scrap supply, which - in combination with an income-sensitive demand results in volatile prices.

It is useful to end this section by commenting on the long-run trend and price formation. Figure 5 shows that between the 1930s and the end of the 1990 s there was a real price decline, but the recent surge in prices implies that the real price is more or less at the same level as it was at the advent of World War II. Still, one should remember that this is a cyclical industry and market actors and government are likely to respond by increasing capacity and educating skilled personnel. These things take time but eventually prices will settle out again. Since steel can be produced from either virgin iron ore or recycled steel, in the long run scrap-based production has to be economically competitive with steel production based on iron ore. This implies that the long-run scrap price will depend on the cost of iron ore and the cost of refining iron ore to steel, so that: price of scrap (long run) $=$ price of iron ore + refining cost (iron ore to steel) - refining cost (scrap to steel) (Jernkontoret 2003). Clearly, in the long run scrap prices will also be influenced by technological change at the mill level, the use of scrap substitutes (DRI) and government regulations (Fenton 2004).

\section{THE MARKET FOR STAINLESS STEEL SCRAP}

Table 7 presents world stainless steel production, and it shows that the share of world production is highest in the Asian countries. The industry organization Euro Inox (2008) asserted that any stainless steel object has an average recycled content of approximately sixty per cent. This suggests that in 2004, a world total of $14,742,000$ metric tons of stainless steel scrap was consumed to produce the reported amount of 24,570,000 metric tons of stainless steel (Table 7).

The International Stainless Steel Forum (2008) provided statistics on international trade flows of stainless steel scrap (Table 8). Most of the trade takes place within Western Europe and Asia, regions in which the biggest producers also reside. Notable exporters are also the NAFTA countries and Eastern Europe. Most of the stainless scrap exports from Eastern Europe go to Western Europe, while NAFTA exports end up mostly in Asia and to some extent in Western Europe. Overall, Table 8 suggests that the market for stainless steel scrap is also essentially global in scope.

The value of stainless scrap mostly lies in its alloying contents $(\mathrm{Cr}, \mathrm{Ni}, \mathrm{Mo})$, and its pricing follows the respective benchmark prices on the London Metal Exchange (LME) with a slight discount. The normal premium for the $\mathrm{Cr}$ and $\mathrm{Ni}$ contents is about eighty-five to ninety-five per cent of the LME alloy prices. Jernkontoret (2003) stated that one ton of stainless steel scrap is roughly ten times as valuable as a ton of carbon steel scrap.

\section{CONCLUDING REMARKS}

This paper has analysed the international market for steel scrap. The steel scrap industry appears to be highly competitive and with a strong global scope. Intensive international trade ensures that

Table 7. Stainless and Heat-resisting Steel - Crude Steel Production, 2004-2005 (I,000 mt).

\begin{tabular}{lrr}
\hline Region & \multicolumn{1}{c}{2005} & \multicolumn{1}{c}{2004} \\
\hline Western Europe/Africa & 8,823 & 9,422 \\
Central and Eastern Europe & 310 & 318 \\
The Americas & 2,688 & 2,933 \\
Asia & 12,498 & 11,897 \\
World Total & 24,319 & 24,570 \\
\hline
\end{tabular}

Source: International Stainless Steel Forum (2008). 
Table 8. International Trade in Stainless Steel Scrap, 2004 (I,000 mt).

\begin{tabular}{lccccccccc}
\hline Origins & \multicolumn{10}{c}{ Destinations } \\
\cline { 2 - 10 } & NAFTA* & $\begin{array}{c}\text { Latin } \\
\text { America }\end{array}$ & $\begin{array}{c}\text { Western } \\
\text { Europe }\end{array}$ & $\begin{array}{c}\text { Eastern } \\
\text { Europe }\end{array}$ & $\begin{array}{c}\text { Middle } \\
\text { East }\end{array}$ & Africa & Asia & Others & Total \\
\hline NAFTA* & 164.9 & 0.9 & 173.8 & 0.0 & 0.1 & 14.8 & 344.8 & 0.0 & 699.5 \\
Latin America & 1.3 & - & 8.8 & - & - & - & 3.8 & - & 13.9 \\
Western Europe & 3.6 & 2.0 & 1528.8 & 42.9 & 8.6 & 1.3 & 276.6 & 0.0 & $1,863.9$ \\
Eastern Europe & 0.7 & - & 459.6 & 2.7 & 0.0 & - & 54.8 & 0.0 & 517.8 \\
Middle East & $\mathrm{n} / \mathrm{a}$ & $\mathrm{n} / \mathrm{a}$ & $\mathrm{n} / \mathrm{a}$ & $\mathrm{n} / \mathrm{a}$ & $\mathrm{n} / \mathrm{a}$ & $\mathrm{n} / \mathrm{a}$ & $\mathrm{n} / \mathrm{a}$ & $\mathrm{n} / \mathrm{a}$ & $\mathrm{n} / \mathrm{a}$ \\
Africa & - & - & 3.8 & - & - & 0.0 & 8.0 & 0.1 & 11.8 \\
Asia & 0.5 & - & 9.5 & - & 0.1 & 0.1 & 687.2 & 0.2 & 697.6 \\
Others & 0.1 & 0.0 & 3.7 & - & - & 0.0 & 42.3 & 1.0 & 47.2 \\
Total & 171.2 & 2.9 & $2,188.0$ & 45.6 & 8.9 & 16.2 & $1,417.5$ & 1.4 & $3,851.7$ \\
\hline
\end{tabular}

* North American Free Trade Agreement.

Source: International Stainless Steel Forum (2008).

scrap flows to its highest value use, and any policy limiting trade will impose a positive (gross) cost. The price of steel scrap is determined by demand and supply forces and, given the significant international scope of the market, the derived demand for steel scrap will be influenced by steel production levels in a large number of countries. China's role in the world steel scrap market has increased significantly over the last decade, but, in terms of steel scrap consumption, the USA is also a big player given its strong reliance on the scrapintensive EAF process. Empirical research confirms the notion of a relatively low own-price elasticity of scrap supply, which - in combination with an income-sensitive demand side - results in volatile short-run price movements.

Experience from the long history of scrap production and use illustrates that supply has adjusted spontaneously to increases in demand. This does not necessarily imply that public policy measures to facilitate scrap collection further (e.g. from households) are economically inefficient. However, any policy intervention that does not rely on an analysis of market behaviour and performance risks causing more harm than good. Public policy should perhaps mainly strive towards overcoming technical hurdles in the scrap-processing industry through basic $R \& D$ support; if further end-uses of waste products are profitable, markets will emerge by themselves.

The paper has also illustrated that previous research on steel scrap markets exists but it is rather limited to time-series analysis of scrap price developments. There exists, therefore, a need to add to this research by focusing in more detail on the demand and supply side of the essentially global market. In the case of the supply side, more attention could be paid to how supply reacts to alterations in the stocks of old and new scrap and if there are significant differences in the short- and long-run own-price elasticity of supply. Such studies ought to constitute an important input to the policy process and to further LCA studies on the use of steel products. The recent demand surge in China and India calls for additional intensityof-use studies at the country level, and the challenges posed by current and future climate policy initiatives also call for new micro-economic studies of the steel scrap market (Ameling and Steffen 2005).

\section{Acknowledgements}

The research undertaken in the preparation of the paper has formed part of the multi-disciplinary research programme "Towards Sustainable Waste Management', hosted by the IVL Swedish Environmental Research Institute Ltd and funded by the Swedish Environmental Protection Agency. Valuable help and support from Tomas Ekvall is gratefully acknowledged, as are constructive comments from an anonymous referee. Any remaining errors, however, reside solely with the authors.

\section{Notes}

1. It is useful to distinguish between carbon steel, a combination of iron and carbon where other elements are present in quantities too small to affect the properties, and stainless steel, which is a term for a variety of alloys which are corrosion resistant due to a chromium content of at least 10.5 per cent 
(Cunat 2004). The present paper focuses primarily on carbon steel but also comments briefly on the market for stainless steel scrap.

2. Integrated companies experienced their last surge of expansion during the early 1970s when steel demand was high. However, as demand growth slowed down towards the end of the decade, these investments proved to be very uneconomical (Crandall 1996).

3. The main principles of the supply of home scrap are essentially the same as those presented for new scrap.

4. Still, at higher price levels the short-run curve will be above the long-run curve since producers at some point encounter capacity constraints (Tilton 1992).

5. Evans (2006) used a univariate approach with periodic autoregression and concluded that the regional US scrap prices also are tied together in the long run. Any short-term movements away from this trend are corrected quickly.

6. They did, however, estimate a separate supply function for home scrap, but found no statistically significant relationship between the supply of home scrap and the price of scrap. In other words, they could not reject the null hypothesis of a zero ownprice elasticity of home scrap supply (Barnett and Crandall 1986).

7. These authors found that US scrap prices increased by 2 per cent during the winter and then fell by 1.3 per cent during the spring (Albertson and Aylen 1996).

\section{References}

Albertson, K, Aylen, J. 1996. Modelling the Great Lakes freeze: forecasting and seasonality in the market for ferrous scrap. Int J Forecast. 12:345-359.

Ameling, D, Steffen, R. 2005. Challenges for the EU steel industry. Ironmak Steelmak. 32(3):187-190.

Aylen, J, Albertson, K. 2006. Markets in ferrous scrap for steelmaking. Ironmak Steelmak. 33(3):203-212.

Barnett, DF, Crandall, RW. 1986. Up from the ashes: the rise of the steel minimill in the United States. Washington (DC): Brookings Institution.

Blomberg, J, Hellmer, S. 2000. Short-run demand and supply elasticities in the West European market for secondary aluminium. Resour Policy 26:39-50.

Bureau of International Recycling [Internet]. 2007. About recycling: ELV processing and recycling; [cited 2007 Nov 5]. Available from: www.bir. org.

Campbell, RF. 1948. The history of basic metals price control in World War II. New York (NY): Columbia University Press.
Chemlink [Internet]. 2007. Direct reduced iron and iron ore; [cited 2007 Nov 6]. Available from: www.chemlink.com.au/dri.htm.

Crandall, RW. 1996. From competitiveness to competition: the threat of minimills to large national steel companies. Resour Policy 22(12):107-118.

Cunat, PJ [Internet]. 2004. Alloying elements in stainless steel and other chromium-containing alloys; [cited 2008 Jan 15]. Available from: www.euroinox.org.

Ekvall, T. 2000. A market-based approach to allocation at open-loop recycling. Resour, Conserv Recycl. 29:91-109.

Emery, A, Williams, KP, Griffiths, AJ. 2002. A review of the UK metals recycling industry. Waste Manag Res. 20:457-467.

EUROFER [Internet]. 2006. Steel recycling; [cited 2007 June 4]. Available from: www.eurofer.org.

EUROFER [Internet]. 2007. Steel statistics; [cited 2007 Nov 5]. Available from: www.eurofer.org.

EFR [Internet]. 2006. The European steel and scrap market - a summary report, March 2006; [cited 2007 Nov 1]. Available from: www.efr2.org.

Euro Inox [Internet]. 2008. The recycling of stainless steel; [cited 2008 Jan 16]. Available from: www.ssina.com.

Evans, M. 2006. A study of the relationship between regional ferrous scrap prices in the USA, 1958-2004. Resour Policy 31:65-77.

Fenton, MD. 2002. Iron and steel scrap, mineral commodity summaries [Internet]. Washington DC: US Geological Survey; [cited 2007 Oct 2]. Available from www.minerals.usgs.gov.

Fenton, MD. 2004. Iron and steel recycling in the United States in 1998. In: Flow studies for recycling metal commodities in the United States. Reston (VA): US Geological Survey. p. G1-G8.

Fenton, MD. 2006. Iron and steel scrap, mineral commodity summaries [Internet]. Washington DC: US Geological Survey; [cited 2007 Dec 3]. Available from www.minerals.usgs.gov.

Fisher, FM, Cootner, PH, Baily, MN. 1972. An econometric model of the world copper industry. Bell J Econom Manag Sci. 3(2):568-609.

Huhtala, A, Samakovlis, E. 2002. Does international harmonization of environmental policy instruments make economic sense? Environ Resour Econom. 21:261-286.

Humphreys, D. 2007. Global commodity demand trends: the emergence of China and India. Paper presented at: The Globalization of 
Primary Commodity Markets, Oct 22; Stockholm.

International Iron and Steel Institute [Internet]. 2006. World steel in figures 2006; [cited 2007 Sep 10]. Available from: www.worldsteel.org.

International Stainless Steel Forum [Internet]. 2008. Online statistics; [cited 2008 Jan 16]. Available from: www.worldstainless.org.

ITC - International Trade Center [Internet]. 2007. International trade statistics 2001-2005; [cited 2007 Sep 10]. Available from: www.intracen.org/ tradstat.

Jernkontoret. 2003. Stålets kretslopp. Stockholm: Rapport i Jernkontorets Forskning No. D 792.

Palmer, K, Sigman, H, Walls, M. 1997. The cost of reducing municipal solid waste. J Environ Econom Manag. 33:128-150.

Sander, Å. 1996. Comment - from competitiveness to competition: the threat of minimills to large national steel companies (by Robert W. Crandall). Resour Policy 22(1-2):119-121.

Söderholm, P. 2006. Environmental taxation in the natural resource extraction sector; is it a good idea? European Environment 16(4): 232-245.
SSINA [Internet]. 2008. The stainless steel information center; [cited 2008 Jan 17]. Available from: www.ssina.com.

Tilton, JE. 1992. Economics of the mineral industries. In: Hartman, HL (ed). SME engineering handbook. $2^{\text {nd }}$ ed. Littleton (CO): SME. p. 47-62.

US Geological Survey [Internet]. 2007. Iron and steel scrap statistics. In: Kelly, TD, and Matos, GR (eds). Historical statistics for mineral and material commodities in the United States. US Geological Survey Data Series 140; [cited 2008 Jan 8]. Available from: pubs.usgs.gov/ds/2005/140/.

Yuzov, OV, Sedykh, AM. 2003. World trends in the formation and use of scrap metal. Metall. 47(5-6):201-205.

Patrik Söderholm

Economics Unit

Luleå University of Technology

97187 Luleå

Sweden

E-mail: patrik.soderholm@ltu.se 